\title{
Property booms and bubbles. A demolition strategy - towards a tabula rasa?
}

\author{
Leonie Janssen-Jansen \\ University of Amsterdam \\ Greg Lloyd \\ University of Ulster
}

\begin{abstract}
There is a tendency to perversity in the effects of public policy for the built environment at large and with respect to specific sectors. This review paper addresses the unanticipated effects arising from the land and property development incentives which prevailed before the current economic recession. In effect, a perverse outcome resulted in the form of a property bubble. There is now also a perversity in terms of public finances being allocated to correct the dysfunctional market sectors. In particular, the use of a demolition strategy to address the oversupply in the land and property stock is a perverse means of addressing market failure. This paper draws on experiences in the Netherlands, the UK and the Republic of Ireland where economic conditions, political priorities and public expenditure cuts have combined to create a dysfunctional land and property domain. The paper questions whether demolition is the appropriate response to the tensions evident in modern land and property development markets.
\end{abstract}

\subsection{Introduction}

The theme of liveability in urban environments offers a considerable challenge to all those property interests involved in the various facets of the built environment. It forms part of the debates around sustainable development and sustainability. It is associated with quality of life questions, well-being and cohesion, and a required balance of economic, social and environmental facets in land and property development. The concept of liveability rests on an integrated approach to urban management and involves a complex of factors such as environmental quality, noise, community involvement, traffic control and the provision and quality of services and facilities (Zuidema \& De Roo, 2009).

Liveability must also involve resource efficiency and justice issues - and is therefore very much a political concept. Indeed, liveability may be seen as a contested concept - as evidenced by the sustainability versus liveability implications of creating compact city environments (Howley et al, 2009). Clearly then, considerations of consumption, production, investment and development in real estate need to be taken into account in devising those conditions which are appropriate to liveability and social and community well-being. In general, students of the built environment tend to assume the relatively efficient and effective operation of land and property development markets. This is held to result in the general balancing of demand and supply for different real estate products - such as housing, office and retail (Ratcliffe et al, 2004). The basic premise is that land and property development markets work efficiently and effectively. Where private land markets fail - such as in creating negative externality effects or in raising questions around the provision of appropriate infrastructure - then this economic reasoning suggests there a case for government intervention through forward planning and regulation of development in order to secure the wider public interest (Peel \& Lloyd, 2008). In such circumstances, the state intervenes to correct the market failures through a combination of policy 
instruments - including regulation, spending, subsidy, and incentive. There are two observations to make about this generalised neoclassical economic approach to understanding how land and property markets work.

First, this perspective offers just one analytical understanding of land and property. It rests on a screed of assumptions about markets - associated with clearly defined private property rights, perfect information, factor mobility, actor rationality and profit seeking. Clearly, this can be extended to include more fundamental considerations of power, influence and control of the resource. In other words, there are more dynamic explanations of how land is used and developed - such as the insights provided by transactions costs perspectives and new institutional economics (Webster, 2005).

Second, there is a tendency to assume the relatively smooth operation of land development cycles - with a general tendency to equilibrium. In such circumstances, any changes in demand, supply and prices are assumed then to even out and move to a balanced outcome. It is assumed there is an intrinsic stability in the system. Related to this assumption is that markets operate in the context of growth. This is certainly the case when market failures are considered - growth creates the available resource by which state intervention can correct the specific efficiency and equity failures. What happens, however, if there is a shock to the system? What happens if there is not a tendency to general equilibrium? What happens if there is a systemic mismatch between supply and demand for land and property development and prices do not function appropriately? What happens if the land and property development markets operate in conditions of no growth - or indeed planned economic contraction? The latter challenges conventional and established sociological, ecological, and economic foundations of a macroeconomics (Alexander, 2012). These changed circumstances may require alternative understandings about market adjustments and state interventions?

This paper draws on experiences in the Netherlands, the UK and the Republic of Ireland where economic conditions, political priorities and public expenditure cuts have combined to create a dysfunctional land and property domain. In effect, the paper seeks to explore new contexts to land and property development, land use planning and policy domains.

\subsection{Changing contexts}

Up to 2007, the Netherlands, the UK and the Republic of Ireland enjoyed a relatively lengthy economic boom which was reflected in expanding construction and building, infrastructure provision, and increased employment, investment, production and standards of living. The Republic of Ireland, for example, may be considered an exemplar of this economic growth with intense land and property development (MacSharry \& White, 2001). The period of economic growth, however, was not even over time or space - and there were important questions about the specific economic geographies created. In the UK, for example, there was a concern that the conventional regional divide between north and south had re-established itself notwithstanding previous government policy interventions to encourage economic convergence (Amin et al, 2003). Indeed, it was argued that the period of economic growth had resulted in a marked redistribution of economic advantage and political power concentrated in a London 'city state' (Ertuck et al, 2011). This stood apart from the 
remaining functional economy. These outcomes represent specific dimensions of the ways in which relatively unregulated market economies operate - encouraged by poorly devised regulations an public policies.

In retrospect, it is evident that the uneven macro-economic expansion in the Netherlands, the UK and the Republic of Ireland was driven by a speculative land and property development bubble - which itself then fed on into the expanding economic circumstances. Available finance, an aggressive construction and property development sector, dynamic land exchanges, price and cost inflation and high (if not unrealistic) expectations resulted in an effective "ratcheting" up of the land and property development sector in the three nation states. This parasitical arrangement eventually led to disastrous outcomes. The credit crunch, the ending of the economic boom which involved the bursting of the property bubble which itself exacerbated the economic downturn followed in short order. Since 2007, however, the Dutch, UK and Irish economies have not experienced this general economic contraction in the same ways - the effects were again unevenly distributed over time and space reflecting the specific structures and processes of each economy. New geographies of economic performance and disadvantage have again emerged at the sub-national levels - prompting different responses in each nation space to recover the conditions for future stability and growth (Lovering, 2010).

A common feature of this post-boom period has been the creation of destabilised and dysfunctional land and property markets. These conditions include a deflated demand for land and property, vacancies in the existing built environment stock, the over optimistic over zoning of land for development, unfinished infrastructure and building projects, and in some instances an over-supply of real estate. There are other underlying characteristics associated with the restricted availability of finance for investment in all land and property development sectors, stagnant market activity and sluggish price movements. The challenge is how to address the over-hang of stock, in effect the over-supply of land and property development which distorts the conventionally understood characteristics of a market economic mechanism.

This paper explores the specific turn to demolition of the existing built environment stock to address these conditions and to create more appropriate market conditions. ${ }^{1}$ It considers the nature of demolition as one approach that is being adopted to resolving the specific over-supply conditions in land and property development sectors. What are the implications of this particular intervention to address the issues associated with mal-functioning land and property sectors? It considers the shock of a malfunctioning land and property sector in which conventional relations have broken down. The paper does not consider the implications of a future zero growth scenario but clearly that remains a possible backdrop to the land and property development sectors.

\footnotetext{
${ }^{1}$ The paper does not, however, consider the establishment of the National Asset Management Agency (NAMA) in the Republic of Ireland in December 2009 to address the problems which arose in its banking sector as the result of excessive property lending. NAMA has acquired loans (land and development and associated loans) from participating financial institutions. Its objective is to obtain the best achievable financial return for the State on this portfolio over an expected lifetime of up to 10 years.
} 


\subsection{Broken down markets?}

The economic boom had been driven by the land and property sectors - and had itself fed the property bubble, often involving more evident speculative activity (Adair et al, 2009). It is important to acknowledge, however, that the origins of the property bubble were highly complex - involving the interweaving of motive (demand), speculative activity (supply) and government positioning. The contributory factors included investment searches for better returns following the dot.com crisis in the early 2000s, relatively low interest rates and an abundance of available finance, and a turn to the buy-to-let real estate sector (Janssen-Jansen \& Mulders, 2012a). This created an inflationary spiral of property prices, speculative land trading, and intense rates of building activity at large - which was particularly evident in the commercial and retail property sectors as shown in the Republic of Ireland (McDonald \& Sheridan, 2008). Together with speculative house building and other construction projects on the assumption of continued growth and demand - framed by the optimistic metrics of the so called New Economy - land and property became an important emblem of the boom (O'Toole, 2009). Significantly, the advocacy of neo-liberal market ideas on government and public policy contributed to the false expectations of what was considered to be a sustainable economic boom.

The layering of the contributory factors must take into account the role of government in this expansionary period. Whilst the private sector was instrumental in feeding the boom and the bubble, government played an important role. In the Netherlands, for example, the established governmental approach through an active land policy resulted in many local authorities being deliberately involved in promoting land and property development. This was a consequence of local authorities engaging in land transactions to secure a value added return which was then hypothecated to the provision of community services and housing, social facilities and infrastructure (Janssen-Jansen, 2012). In the Republic of Ireland, relatively lax land use regulations over speculative land and property development prevailed - enabling the unrealistic building programmes to take place (Kitchen et al, 2010). This was particularly evident in the residential sector.

The effects of the ending of the economic boom and the bursting of the property bubble are evident in a number of characteristics in land and property in the Netherlands, UK and Ireland. First, on the demand side - the combination of economic contraction, industrial and corporate restructuring, the restricted access to finance through the banking sector, the policies of austerity regarding public finance and expenditures, the lack of consumer and industrial confidence, the wider economic and social impacts such as increased unemployment have served to deflate demand for land and property. Over and above this, structural shifts in demography, such as the aging population; new geographies of economic performance; and the slowing up of markets have served to exacerbate the demand side of the equation. This is an important consideration - as demand is the principal driver in land and property development markets. Over and above the structural dimensions of a deflated demand there is a spatial dimension with geography proving to be an important factor in the wider public interest.

Second, there is evidence of unfinished and stalled infrastructure and building projects. The construction of the new tram network in Edinburgh is a case in point. It was devised in the boom period to serve the best interests of 
Edinburgh as the economic and political capital of a devolved Scotland. Although there were project management issues around cost over-runs and problems with the construction the overall economic contraction inhibited the availability of public funds. The outcome will be a reduced network for the city. This will inevitably have implications for new inward investment and the confidence and image of Edinburgh as the capital city of a devolved Scotland and a World heritage Site. ${ }^{2}$ The wider implications of incomplete infrastructure provision are legion - with likely negative impacts on associated development projects, economic stability, community well-being and environmental considerations. There is an emerging debate about the importance of infrastructure investment to address the issues around the vulnerability of the natural environment (New Economics Foundation, 2009). This suggests that there are considerable opportunity costs to the infrastructure deficit in completion.

Thirdly, there are issues associated with vacancies in the existing built environment stock. Evidence from the Netherlands shows that the office sector has demonstrated relatively high vacancy rates since the mid 2000s. Currently, the national vacancy rate exceeds $14 \%$ but in geographical terms there are evident variations with some cities, or business areas within cities, showing vacancy rates of over $40 \%$. Even in those areas which are relatively over-performing in economic terms are characterized with high office vacancy rates. Compared with other European office cities, the overall office vacancy rate in Amsterdam is high (Janssen-Jansen, 2012; see table 1). An implication of these conditions is that, even within a highly segmented sector, uncertainties are created for future investment opportunities. Questions also rise as to the sustainability of funding streams particularly the re-mortgaging of existing loans - for the office development sector. A longer term impact could be seen with respect to macroeconomic stability (DNB, 2011).

Notwithstanding the vacancy issue, new offices are still being built in the Netherlands. This suggests that the total supply of office space will continue to increase exacerbating existing uncertainties. Furthermore demand for office space is forecast to decline (CPB, 2012). This is a consequence of changing ways of working to secure greater flexibility; technological innovation enabling more office workers to operate from home; and economizing strategies by office occupiers to manage their real estate costs.

Fourth, an over-supply of real estate is evident elsewhere with respect to residential sectors. In the Republic of Ireland there is a very evident over-supply of housing across its national space. The so called 'ghost estates' phenomenon is a direct consequence of speculative building activity during the economic boom. This was encouraged by lax financial arrangements enabling available funding and over zoning by local authorities and relatively weak planning controls (Kitchen et al, 2010). The over-supply is dramatically expressed in terms of 'haunted landscapes' and 'ghost estates'. The evidence suggests there are over 300,000 vacant properties in the Republic of Ireland - excluding holiday homes this falls to 228,000. The oversupply is estimated at 103,000 houses.

\footnotetext{
${ }^{2}$ http://www.scotsman.com/news/edinburgh-s-disgrace-ii-tram-fiasco-threatens-to-further-embarrass-capital-1-1680151
} 
Table 1: office vacancy rates in main office markets in Europe (Q1 2012)

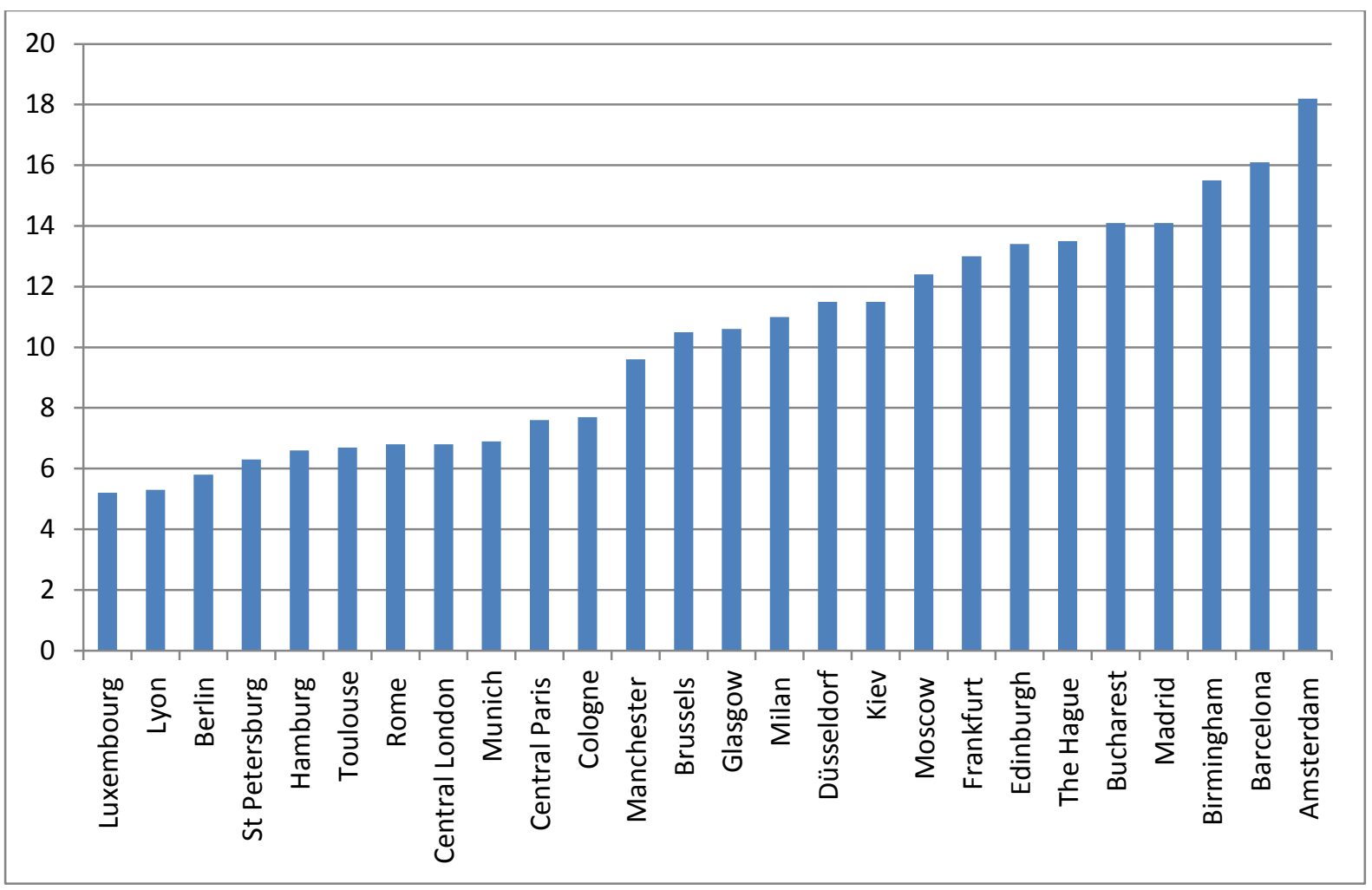

Source: BNP Paribas 2012, p. 9

Indeed, whilst the evidence reveals the complexities involved in reaching these estimates it suggests that 620 ghost estates have been created since 2005 with nearly 20,000 units involved. There are considerable geographical variations across national space. Even more inexplicable is that the study shows those local authorities that had the most vacant stock in 2006, subsequently built the most new housing. Moreover these authorities now have the largest surpluses of stock and have the most land zoned for future use. The evidence shows that there is a mix of complete, active and non-active development sites across Ireland. A geographical feature is that the un-started residential developments are clustered around the two major cities Dublin and Cork. The estimates of over-supply and the dramatic position have been contested - as shown by a National Survey conducted by the Irish Government but it has nevertheless prompted action to address the issues (Department of the Environment, Heritage and Local Government, 2010). This has resulted in a strategic management approach by the Government to create a co-ordinated approach to complete unfinished housing developments, to address any associated public safety issues, to strengthen the legislative framework and to inject confidence into the sector (Department of Environment, Community \& Local Government (2012).

In the Netherlands the issue of over zoning has also contributed to the ongoing development momentum. Yet, although the financial consequences for municipal governments and market players have become very clear, responses are still slow or even absent. (Janssen-Jansen \& Mulders, 2012b).

Finally, the disruption to the property sector is evident in ongoing legal arguments around the non compliance of contracts to purchase property. In Northern Ireland for example the time lag between a promise to purchase a new apartment (which included a deposit) and the completion of the property involved a downward movement 
in values. This created a very real negative equity position for intending purchases. Not surprisingly many intending purchasers tried to avoid completing the contract. This has led to legal actions on the part of the developers (Adair et al 2010). The evidence suggests a number of perverse effects relating to the overall performance of the market economies, the viability of their land and property development sectors, the operation of the demand and supply side activities, the role of government and the impact of incentives put into place.

\subsection{A demolition derby?}

Taken together these conditions suggest a damaged sector which requires considerable state support to correct its relationships and activities, the disruption of the important construction sector and its supply chain linkages, the impact of the building downturn on the labour market and attendant skill leakages, the impact on consumer confidence, and the negative perception of the land and property development sectors. There is also a knock on effect in terms of how government should respond to these uncertainties. In England, for example, there is a complex debate taking place around the perceived role and purpose of land use planning in such conditions. Influenced by neo-liberal economic ideas a process of planning reform has been put into place which has abolished the arrangements for regional spatial planning and which has effected a reversion to local control and decision making arrangements via the National Planning Policy Framework. This response is itself highly contested - reflecting two dynamic traditions in Conservative thinking about planning. On the one hand, there is the libertarian tendency that favours the free market and, on the other hand, the equally powerful rural lobby that seek greater protectionism of land and property (Goodchild, 2010). This position is itself exposed to further criticism to further reduce the level of planning intervention in such restricted economic conditions and poorly performing land and property development markets (Niemietz, 2012). Governments are clearly reaching out to devise appropriate responses to this crisis in their land and property development markets.

In order to address the deflated demand and over-supply conditions - with the associated confused price signals - there is now an interest in demolition to clear the redundant back log, rebalance supply and demand, and recreate the market conditions to ensure a new phase of investment and development. In the Netherlands, for example, there is support from central government, the regional governments and a number of municipalities for initiating a demolition strategy of obsolete office buildings. In June 2012 for example those stakeholders involved in the sector signed an agreement to collaboratively address the Dutch 'tragedy of the offices' (Ministry of Infrastructure and the Environment; Janssen-Jansen, 2012). Part of this agreement is to involve a 'demolition fund', aimed at offering financial assistance to owners of redundant office buildings who decide to take the stock out of the market. Details on how the fund will be financed are yet unclear, but the city of Amsterdam has pledged financial support for this 'demolition fund'.

A similar call to demolish 200,000 houses has been made in the Republic of Ireland. ${ }^{3}$ Demolition is not the only approach - in the Republic of Ireland, for example, there is an attempt to ensure completion of housing

\footnotetext{
${ }^{3}$ http://news.bbc.co.uk/1/hi/world/europe/8653238.stm
} 
developments - using public safety as a rationale for intervention. Yet, demolition represents a dramatic approach to resolve a specific facet of the property crisis - the over-supply which is destabilising markets.

What is the purpose of a demolition strategy to address the specific land and property development market conditions? There are a number of rationales for demolition of an excess built environment stock that may be identified.

- To clear the backlog of excess stock to better enable a balance between supply and demand for real estate; in effect, to create the conditions in which a new process to a market equilibrium can be secured.

- To address the vacant property issue to encourage a move to restore the price equilibrium; in effect, to remove a surplus and encourage a new demand impetus in the market.

- To create a clean slate for the market to allow a new phase of investment and development in the built environment to take place; in effect, the write off the 'bad debt' of the speculative boom.

- To kickstart the construction sector through demolition and rebuild; in effect, to reflate the land and property development sector and enhance its macro-economic contribution.

- To enhance the liveability of communities and urban areas; in effect, by removing the negative aspects of surplus stock and to provide a fresh start under new conditions.

At first sight (and from a neoclassical economic perspective) the demolition of surplus property appears a rational means of clearing an oversupply of the built environment and of injecting a fresh impetus into the specific sectors. In effect, it is a way of clearing the decks, of re-creating more manageable demand/ supply conditions and allowing market processes to operate without a legacy of over-supply. Demolition may be seen as a direct approach of re-establishing conditions in which a new market process and equilibrium can be secured. This can work on both demand and supply sides. Certainty is returned to the market to encourage a fresh demand for land and property development; and supply can start again without the overhang of surplus property.

Further, there is an important argument relating to the multiplier effects of such an exercise. By clearing the negative legacy of an over-supply a new phase of building can take place in which employment would be created, demolition firms engaged and this will involve a reflationary effect on the local and regional economy and this can be then be increased if new construction activity follows the demolition. Creating new spaces may also offer opportunities to develop new environmentally appropriate development and infrastructure forms. Taken together, then, the demolition option appears to suggest a way in which the previously prevailing market conditions can be recreated. Yet, the demolition option raises a number of questions for land and property development markets.

First, the complexity of land and property development markets would suggest that it is not simply a matter of re-establishing a more functional demand/ supply balance. Real estate involves a composite of property rights, investment and expectations - and a physical removal of property involves these deeper considerations. The impact of the over-supply will have changed state-market-civil relationships in such a way that confidence in 
property markets may have been adversely affected. The tendency to legal action as a response to the property over-hang may create a negative identity for land development in the future. Time does not stand still and there may be changes in both demand and supply sides - the leakage of labour and skills from the construction sector, for example, may have take place when the markets were stalled. There are possible inhibiting factors created which may hold up the return to full working in the land and property sectors.

Second, there is the question of cost and compensation. These considerations will inevitably be involved and raise the question as to who pays? It is likely this will fall to the state - effectively compensating previous private sector speculative behaviour, mitigating the effects of that process, and creating new rules to adapt to the over-supply of land and property. The financial considerations involved will serve to further politicise the issue and raise important questions as to the redistribution matters involved.

Third, there are questions as to conducting a large scale demolition exercise and creating the spaces for alternative uses. These may not be real estate developments as the strategic morphology of markets will likely have changed. Demolition will involve restitution and remediation of the land - it is not simply a 'knocking down' exercise - it will involve the effective renewal of the land resource. There are important logistical, regulation and management issues associated with the actual physical demolition programme itself and the recycling of the materials involved. All of this can create a very different view of the land and property development sectors in modern states.

\subsection{Conclusions}

These instances offer insights in the prevailing tendency to perversity in public affairs. The incentives in place during the so called boom created the current economic miasma with a very real imbalance in property sectors. There is now the perversity of public finances being allocated to correct the dysfunctional market sectors in demolishing the excess stock. There are transactions costs involved in addressing the associated property rights, compensation and ownership considerations. There are also opportunity costs in this strategy at a time of severe austerity and competing demands to mitigate the wider social and community costs of the recession. Questions must also be asked about the levels of public subsidy which would need to be directed to correct a private mismatch; the extent to which the public sector is it self-implicated in creating the over-supply; and the extent to which we understand the complexities of property sectors undergoing significant demolition activity.

\subsection{References}

Adair A, Berry J, Haran M, Lloyd MG \& McGreal S (2009) The Global Financial Crisis: Impact on Property Markets in the UK and Ireland. Jordanstown, University of Ulster Real Estate Initiative, March.

Adair A, Berry J, Haran M, Lloyd MG \& McGreal S (2010) Impact of the Recession on the Property Market in Northern Ireland: Contractual Non-Compliance. Local Economy 25(2), pp. 131 - 142.

Alexander S (2012) Planned economic contraction: the emerging case for degrowth Environmental Politics, 21(3), pp. 349-368. 
Amin A, Massey D \& Thrift N (2003) Decentering the Nation. A radical approach to regional inequality. London, A Catalyst Paper. September.

BNP Paribas (2012) Property report main office markets in Western Europe, Q3 2012, Issy-les-Moulineaux: BNP Paribas.

CPB - Centraal Plan Bureau (2012), Kantorenmarkt in historisch en toekomstig perspectief [Office market in historical and future perspective], The Hague: CPB

Department of the Environment, Heritage and Local Government (2010) National House Development Survey. Dublin, October.

Department of Environment, Community \& Local Government (2012) Resolving unfinished housing developments, Progress Report on Actions to Address Unfinished Housing Developments, Dublin.

DNB - De Nederlandse Bank (2011), Overzicht Financiële Stabiliteit in Nederland [Financial stability in the Netherlands review], The Hague, De Nederlandse Bank.

Ertuck I, Froud J, Johal S, Leaver A, Moran M \& Williams K (2011) City state against national settlement. UK economic policy and politics after the financial crisis. Milton Keynes, Centre for Research on SocioCultural Change, June.

Goodchild B (2010) Conservative party policy for planning: caught between the market and local communities. People, Place \& Policy Online 4(1), pp. 19 - 23.

Howley P, Scott M \& Redmond D (2009) Sustainability versus liveability: an investigation of neighbourhood satisfaction Journal of Environmental Planning and Management, 52(6), pp. 847-864.

Janssen-Jansen LB (2012) The Dutch Office Space Tragedy, unlocking the lock-in in Hartmann T \& Needham B (Eds), Planning by Law and Property Rights Reconsidered, Aldershot, Ashgate, pp. 189-205.

Janssen-Jansen L \& Mulders M (2012a) Ontwikkelingsbubbles en planningsdromen, Rooilijn 2012 (4), forthcoming.

Janssen-Jansen LB \& Mulders MJCB (2012b) Leegstand, braakliggende terreinen en ontwikkelingsluchtbellen: een nieuw hoofdstuk in de stedelijke ruimtelijke ordening, Bestuurskunde, 2012 (1), pp. 33-40

Janssen-Jansen LB (2012) The Dutch Office Space Tragedy, unlocking the lock-in in Hartmann T \& Needham B (Eds), Planning by Law and Property Rights Reconsidered, Aldershot, Ashgate, pp. 189-205.

Kitchen R, Gleeson J, Keaveney K \& O’Callaghan C (2010) A haunted landscape: Housing and Ghost estates in Post-Celtic Tiger Ireland. Maynooth, National Institute for Regional and Spatial Analysis, Working Paper 59, July.

Lovering J (2010) Will the Recession Prove to be a Turning Point in Planning and Urban Development Thinking? International Planning Studies, 15(3), pp. 227-243.

McDonald F \& Sheridan K (2008) The Builders. Ireland, Penguin.

MacSharry R \& White P (2001) The Celtic Tiger, Dublin, Mercier Press.

Ministry of Infrastructure and the Environment (2012) Kantorenconvenant Aanpak Leegstand Kantoren [Agreement on Office Vacancy Program], signed by involved public and private stakeholders on June $27^{\text {th }} 2012$ in The Hague. www.rijksoverheid.nl/bestanden/documenten-enpublicaties/brieven/2012/06/28/convenant-aanpak-leegstand-kantoren/lp-i-m-0000002280.pdf 
New Economics Foundation (2009) A Green New Deal: Joined-up policies to solve the triple crunch of the credit crisis, climate change and high oil prices. London, New Economics Foundation.

Niemietz K (2012) Abundance of land, shortage of housing. London, The Institute of Economic Affairs. IEA Discussion paper No. 38, April.

O’Toole F (2009) Ship of Fools: How stupidity and corruption sank the Celtic Tiger. Dublin, Faber \& Faber.

Peel D \& Lloyd MG (2008) Governance and planning policy in the marine environment: regulating aquaculture in Scotland The Geographical Journal, 174(4), pp. 361-373.

Ratcliffe J, Stubbs M \& Shepherd M (2004) Urban Planning and Real Estate Development, London, Spon, Second Edition.

Webster CJ (2005) The New Institutional Economics and the evolution of modern urban planning: Insights, issues and lessons'. Town Planning Review 76(4), pp. 471-501

Zuidema C \& De Roo G (2009) Towards Liveable Cities: Progress in the European Union Urban Environmental Agenda European Planning Studies, 17(9), pp. 1405-1419. 